\title{
サブナノ格子物質中における水素が誘起する新機能
}

$\begin{array}{lllll}\text { 亀川厚則 }{ }^{1} & \text { 中東 } & \text { 潤 }^{2} & \text { 山口 } & \text { 明 } \\ \text { 山内美 穂 } 4, * 1 & \text { 北川 } & \text { 藤田 麻 } \text { 哉 } 1^{5, * 2} & \text { 岡田益 男 } & \end{array}$

\author{
1東北大学大学院工学研究科 \\ 2 福山大学工学部 \\ 3 岩手大学大学院工学研究科 \\ 4 北海道大学触媒化学研究センター \\ 5 九州大学大学院理学研究院化学部門
}

J. Japan Inst. Metals, Vol. 73, No. 3 (2009), pp. 141-150

Special Issue on Emergent Researches for Substitution to and Effective Usage of Rare and Scarce Metals (2) (C) 2009 The Japan Institute of Metals

OVERVIEW

\section{Hydrogen-Induced New Functions in Sub-Nano Lattice Matter}

Atsunori Kamegawa1, Jun Nakahigashi², Akira Yamaguchi³ ${ }^{3}$ Asaya Fujita ${ }^{1}$, Miho Yamauchi ${ }^{4, * 1}$, Hiroshi Kitagawa ${ }^{5, * 2}$ and Masuo Okada ${ }^{1}$

${ }^{1}$ Graduate School of Engineering, Tohoku University, Sendai 980-8579

${ }^{2}$ Fuculty of Engineering, Fukuyama University, Fukuyama 729-0292

${ }^{3}$ Graduate School of Engineering, Iwate University, Morioka 020-8550

${ }^{4}$ Catalysis Research Center, Hokkaido University, Sapporo 001-0021

${ }^{5}$ Department of Chemistry, Faculty of Science, Kyushu University, Fukuoka 812-8581

This paper includes some results of "Hydrogen-Induced New Functions in Sub-Nano Lattice Matters" accomplished by MEXT's program "Elements strategy Project". In the 21st century, the era concerning about environment, this research achievement utilizing hydrogen as the technology for strengthening alloys will be expected to make a breakthrough in the metal heattreatment and processing technology as the new environmental conscious process. Hydrogen heat-treatments for grain-size refinements of alloys were performed. The grain size of $\mathrm{Cu}-3$ mass\% $\% \mathrm{Ti}$ alloy turned into about $20 \sim 50 \mathrm{~nm}$ after hydrogenation and dehydrogenation treatment. Moreover, grain-size refined Ti-based alloy showed large super-elastic elongation. On the other hand, hydrogen induced functions in the alloys were also investigated. Hydrogen transmitting films with Pd nanogranular particles dispersed in ceramic material were developed as attachment of metal-hydride switchable mirrors. Metamagnetism transition temperature $(\mathrm{Tc})$ could be increased by hydrogen introduction in $\mathrm{La}\left(\mathrm{Fe}_{x} \mathrm{Si}_{1-x}\right)_{13} . \mathrm{Pd} / \mathrm{Pt}$ core-shell type nano-particles were also investigated.

(Received October 28, 2008; Accepted January 6, 2009)

Keywords: hydrogen-induced function, hydride, grain-refinement, metamagnetism, core-shell, nano-particle

\section{1. 緒}

$\overline{\overline{\bar{D}}}$

20 世紀は生産活動を生活拠点とする「経済の世紀」であ ったが，これから我々の目指す 21 世紀は「環境重視の世紀」 である．先進国の高度な経済活動に伴う化石燃料の使用によ る地球環境の問題として, 都市の大気污染, 二酸化炭素によ る地球の温暖化などが焦眉の課題として提起されている. 水 素はほとんど無限に存在すると考えられる水が原料であり, クリーンな究極のエネルギー源として期待されている. 第 3 期科学技術基本計画に拈いても, 水素関連プロジェクトは省

*1 独立行政法人科学技術振興機構さきがけ (Japan Science and Technologiy Agency, PRESTO)

*2 独立行政法人科学技術振興機構戦略的創造研究推進事業 (Japan Science and Technologiy Agency, CREST)
庁横断の連携施策プロジェクトとなっていることから鑑みて も「水素」は 21 世紀を担うキーエレメントと見なされてい る.

最近, 材料分野では, 21 世紀に向けての環境調和型材料 プロセスの一つとして, 水素が水素原子の形でサブナノ格子 物質に侵入し, 結晶構造や組織を変化させ, 特性を向上させ るなど有能なプロセス機能を持つことが報告され，水素原子 を積極的に利用しようとする技術が注目されている．これま での材料科学に抢ける水素は, 鉄鋼の “水素脆性” に代表さ れるように, 害のある “やっかいもの” の元素としての位置 付けであった．サブナノ格子物質中に侵入できる元素とし て, 水素原子(プロチウム), 窒素原子, 炭素原子などがある が, 水素原子は全ての元素の中で, 最小の半径を有し, サブ ナノ格子物質中を自由に飛行し, 抜け出せることが可能な唯 一の原子である。 
前述したように，鉄鋼材料の水素脆性に挙げられるように 水素脆化のメカニズムや，いかに金属材料中の水素を低減す るかを焦点とした研究が一昔前までは盛んであったが, 1960 年後半の水素吸蔵合金の発見により, Ni-MH 電池負極 材料や水素エネルギー媒体としての水素を貯蔵する材料の研 究が盛んになってきた。一方で, 本稿のように材料に拈ける 水素という元素を有効に利用し，材料の新規創製や高性能 化，新しい機能の発現を目指した取り組みについても近年精 力的に取り組みが成されてきている.

平成 19 年度より文部科学省・元素戦略プロジェクトが開 始された. 著者らも本稿題目と同じ「サブナノ格子物質中に 颃ける水素が誘起する新機能」というテーマで参画してい る.この目的は, 21 世紀へ向けての環境重視という強い社 会的要求の背景の中で, 水素原子が有するナノ加工プロセス 機能や, 水素原子が材料中に固溶し, ぞのような新規機能を 発現するか等, 水素が有するポジティブな機能を多面的に理 解するとともに，それぞれの材料の特性を飛躍的に向上させ ることに取り組むことである.

\section{2. 水素が誘起するナノ加エプロセス機能}

\section{1 水素吸放出処理による $\mathrm{Cu}$ 系合金などの結晶粒微細化}

金属材料中へ水素を用いて微細結晶粒を得る方法は，永久 磁石材料であるネオジム系磁石への適用が実用材料で初めて の報告であろう。磁性化合物である $\mathrm{Nd}_{2} \mathrm{Fe}_{14} \mathrm{~B}$ を 700 $800^{\circ} \mathrm{C}$ の範囲に抢いて水素雾囲気中で熱処理 (水素化)を施す ことにより, 式 (1)に示すような不均化反応が起こり, 主 相 $\mathrm{Nd}_{2} \mathrm{Fe}_{14} \mathrm{~B}$ 化合物が 3 相に分解し, $\mathrm{Fe}$ 中に微細な $\mathrm{NdH}_{2}$ および $\mathrm{Fe}_{2} \mathrm{~B}$ を生成する. 次にこの分解温度範囲において熱 処理䨌囲気を水素から真空に切り替えて強制的に脱水素を施 すと，式(2)に示すように $\mathrm{NdH}_{2}$ から水素が放出され，そ
れと同時に $\mathrm{Nd}$ が $\mathrm{Fe}_{2} \mathrm{~B}, \mathrm{Fe}$ と再結合を起こしてく001〉に配向 したサブミクロンオーダーの $\mathrm{Nd}_{2} \mathrm{Fe}_{14} \mathrm{~B}$ 化合物相が形成さ れ, 残留磁化と保磁力がともに増大し高特性の磁石粉末とな $ろ^{1)}$.

$$
\begin{aligned}
& \mathrm{Nd}_{2} \mathrm{Fe}_{14} \mathrm{~B}+2 \mathrm{H}_{2} \rightarrow 12 \mathrm{Fe}+2 \mathrm{NdH}_{2}+\mathrm{Fe}_{2} \mathrm{~B} \\
& 12 \mathrm{Fe}+2 \mathrm{NdH}_{2}+\mathrm{Fe}_{2} \mathrm{~B} \rightarrow \mathrm{Nd}_{2} \mathrm{Fe}_{14} \mathrm{~B}+2 \mathrm{H}_{2}
\end{aligned}
$$

この一連の反応は HDDR (Hydrogenation Disproportionation Desorption Recombination) 反応と呼ばれている1)。こ の反応は $\mathrm{Sm}$ 系磁石材料や $\mathrm{Mg}$ 系材料 ( $\mathrm{AZ}$ 系や $\mathrm{ZK}$ 系)など でも適用できることが知られている.

一方で, 著者らは水素との親和力の弱い $\mathrm{Al}$ 系や $\mathrm{Cu}$ 系合 金に, 水素との親和力の強い $\mathrm{Mg}$ を約 $1 \sim 8$ mass $\%$ 固溶 (Al 系合金) せ，水素の吸放出熱処理を施すことにより，結晶粒 をナノ化させることに成功した2,3). $\mathrm{Al}$ などの水素との親和 力の弱い元素を主元素とする合金においても, $\mathrm{Mg}$ などの水 素との親和力の強い元素を含有させておけば, HDDR 現象 は発現するという予測から, 次の式で示すように現用の Al$7.8 \mathrm{mass} \% \mathrm{Mg}$ 合金を $350^{\circ} \mathrm{C}$ で水素中熱処理を施すと, 不均 化反応を起こし， $\mathrm{Al}$ と $\mathrm{MgH}_{2}$ とに分解する. 引き続き同温 度で脱水素熱処理により元の合金組成に復元し，10～ $20 \mathrm{~nm}$ 程度の $\mathrm{Al}$ の超微細結晶粒が観察された。この結果は, その 他の水素との親和力の弱い合金系においても合金組成中に水 素と親和力の強い $\mathrm{Mg}$ や $\mathrm{Ti}$ 等が含まれることにより, HDDR 現象の発現と結晶粒微細化の可能性があることを示 唆している.

そこで今回は，現用のバネ材料銅合金であり析出硬化型と して知られるチタン銅合金の二元系材 $\mathrm{Cu}-3$ mass $\% \mathrm{Ti}$ 合金 について本水素吸放出処理の効果について調査した. 厚さ $30 \mu \mathrm{m}$ の $\mathrm{Cu}-3$ mass\% $\% \mathrm{Ti}$ 䈃に, 水素圧 $7.5 \mathrm{MPa}$ で 48 時間, 300- $400^{\circ} \mathrm{C}$ の水素中熱処理を施した. その電子顕微鏡像 Fig. 1 に示す. 水素処理温度を $350^{\circ} \mathrm{C}$ とすることで, $\mathrm{Cu}$ 母相の

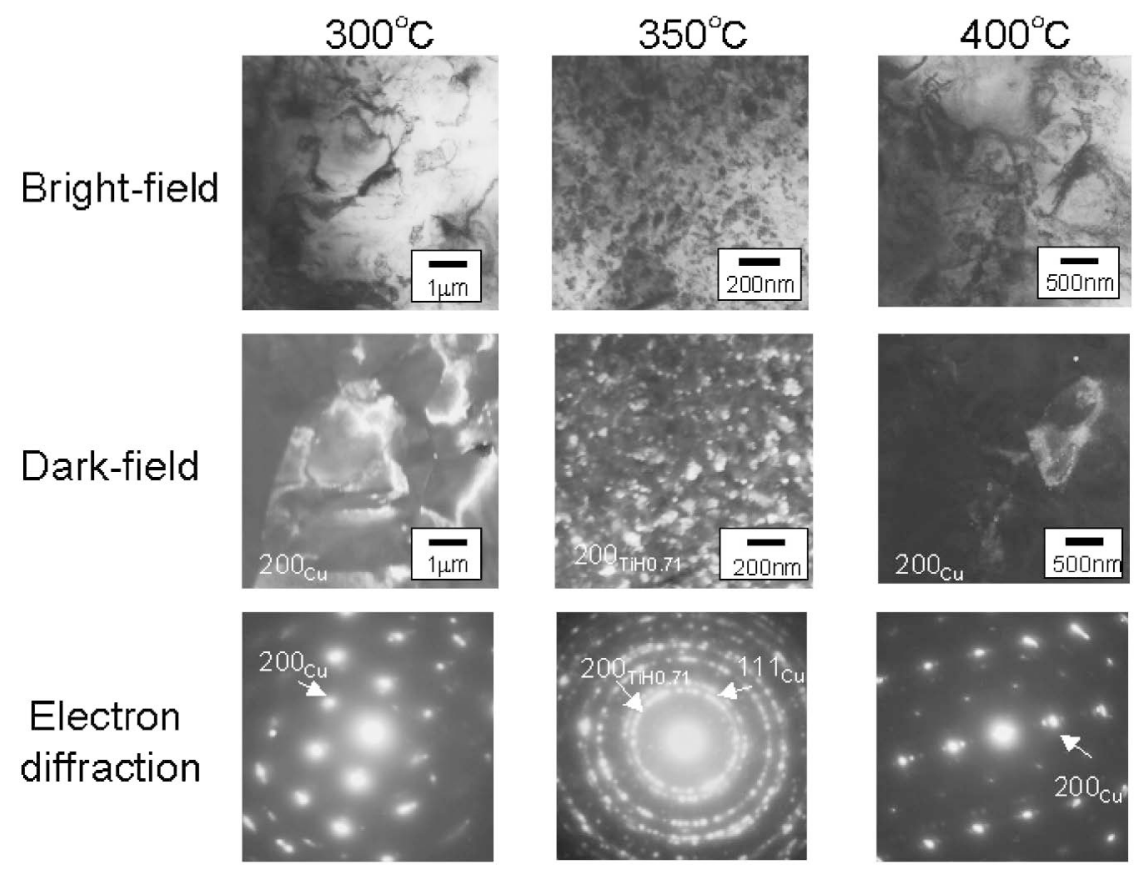

Fig. 1 Bright-field and dark-field images and electron diffraction of the $\mathrm{Cu}-3$ mass $\%$ Ti alloys after hydrogenation at $300-400^{\circ} \mathrm{C}$ under 7.5 MPa of hydrogen for 48 hours. 
fcc 相の他にチタン一水素化物に相当する $\mathrm{TiH}_{x}$ で同定され るディフラクションパターンを得た。従って, $\mathrm{Cu}-3$ mass\% $\mathrm{Ti}$ 合金に水素吸収処理を施すことにより，fcc 相とチタン水 素化物相に不均化することが分かった。この $350^{\circ} \mathrm{C}$ で水素 化した $\mathrm{Cu}-3$ mass\% $\% \mathrm{Ti}$ 合金試料について水素の mass 放出 スペクトルを測定したところ, 約 $400^{\circ} \mathrm{C}$ から水素が放出を 始め, 約 $550^{\circ} \mathrm{C}$ 付近で放出ピークを観察した (Fig. 2).この 結果を受けて, $350^{\circ} \mathrm{C}, 48$ 時間で $7.5 \mathrm{MPa}$ の水素吸収処理に

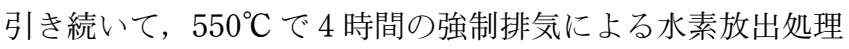
を施し，その微細組織を Fig. 3 に示す。先に観察されたチ タン水素化物のディフラクションパターンは消失し, リング 上に繋がった $\mathrm{Cu}-3$ mass\% Ti による fcc 相を観察した。こ の結果より水素吸放出処理を $\mathrm{Cu}-3$ mass \% Ti 合金に施すこ とにより HDDR 現象が発現し，しかも Fig. 4 に見られるよ うに $\mathrm{Cu}-\mathrm{Ti}$ 母相の結晶粒径は 20-50 nm に超微細化したこ とが判明した. 今後は, HDDR 処理により超微細化された $\mathrm{Cu}-3$ mass \% Ti 䇤の引張強度などの变化について調査して いく予定である.

\section{$2.2 \alpha+\beta 2$ 相型チタン合金の水素処理と超塑性}

チタン合金については, 合金への水素吸収処理後に, 機械 加工を施し, 脱水素処理することにより超微細粒が達成され る. 水素処理は, (1)水素吸蔵, (2)溶体化・マルテンサイト化

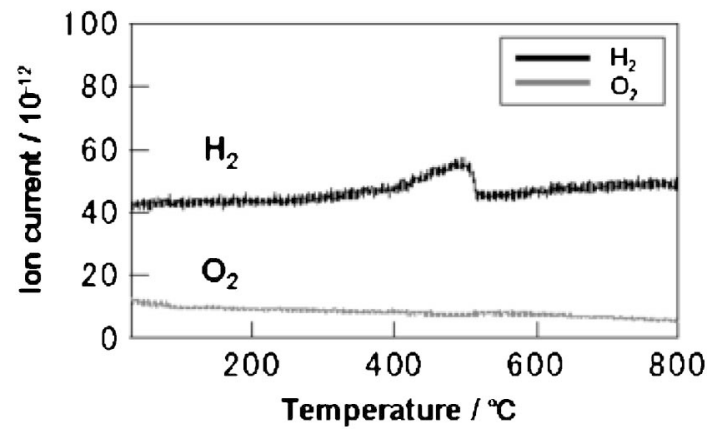

Fig. 2 TG-DTA-mass spectra of the hydrogenated $\mathrm{Cu}-3$ mass\% Ti alloy.
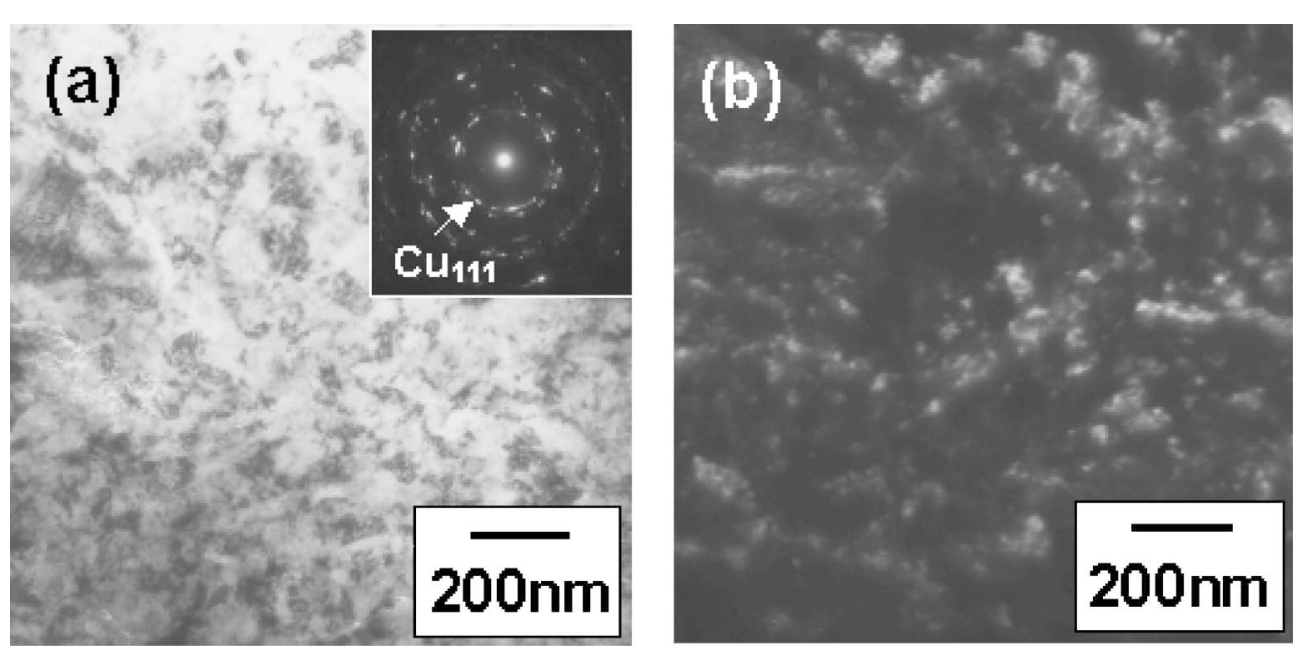

Fig. 3 TEM micrographs of $\mathrm{Cu}-3$ mass $\%$ Ti alloy after dehydrogenation at $550^{\circ} \mathrm{C}$ for 4 hours in vacuum. (a) bright and (b) dark $[\mathrm{Cu}(111)]$ images.

（焼入れ），(3)熱間圧延，(4)脱水素処理の 4 工程で成り立っ ている. $\alpha(\mathrm{hcp})+\beta(\mathrm{bcc})$ 型 2 相型チタン合金に適量の水素 ( Ti-6Al-4V 合金で約 0.5 mass \%) を吸蔵させることによ $り$, 水素は $\beta$ 相安定型元素であるが故に $\beta$ 変態点は低下す る. よって通常よりも低い温度で $\beta$ 単相領域に打ける溶体 化処理が可能になり， $\beta$ 粒をある程度小さくすることができ る. その後, 再結晶粒の核となりうる析出物サイトを多く, かつ分散して導入するため, マトリックスに高密度転位を導

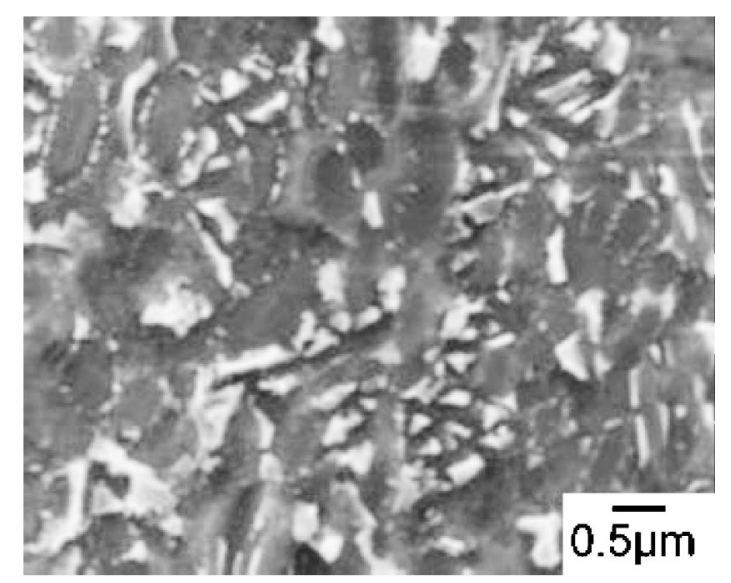

Fig. 4 SEM photograph of ultra-fine-grained Ti-6Al-4V alloy obtained through hydrogen treatment ${ }^{4}$.

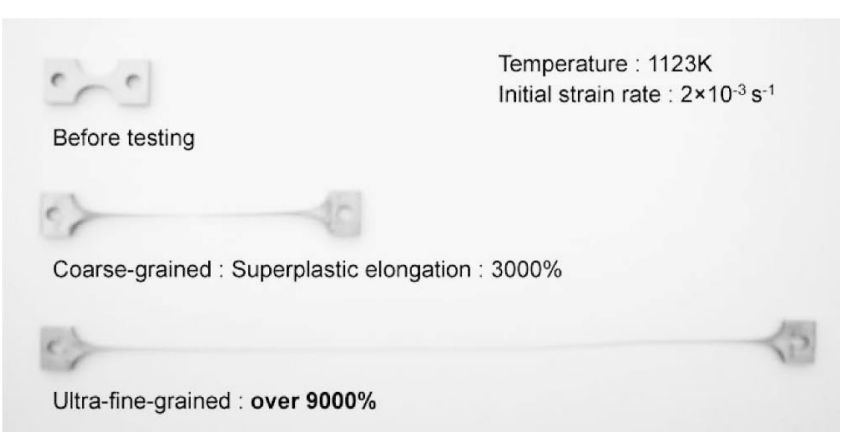

Fig. 5 Superplastic elongation of ultra-fine-grained Ti-3Al$2.5 \mathrm{~V}$. 
入する. そのために，(1) $\beta$ 単相領域からの水冷による焼入れ によって，微細な針状マルテンサイト相を多く生成させ， $\beta$ 相の細分割化と変態による転位の均一分布を図る. (2) $\alpha+\beta 2$ 相領域での熱間圧延によって針状マルテンサイトを微細粉砕 し, 高密度転位領域の形成をより促進させる。このことよ り，析出物の緻密分散化とさらなる高密度転位の局所的な導 入を図る。この一連の処理によって水素化物析出サイトをよ り多く，かつ均一に分散することができる.この状態より脱

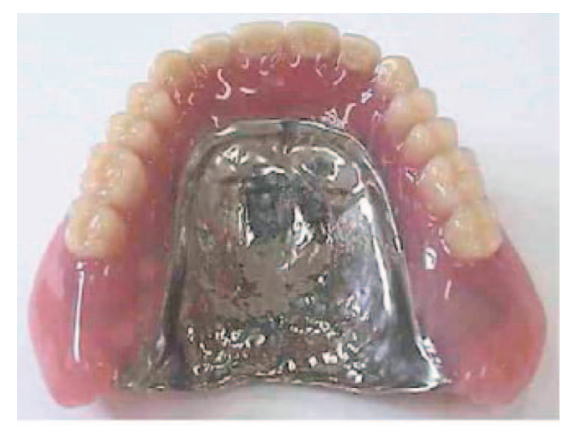

(a) Denture base

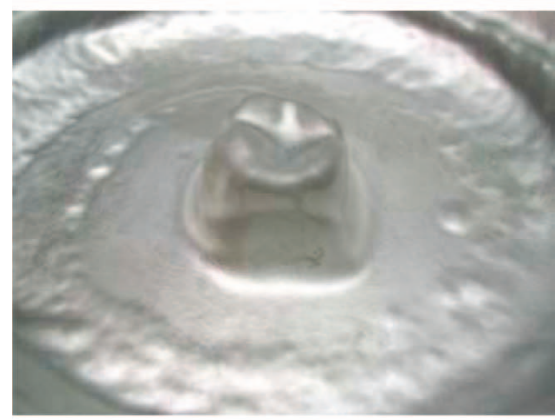

(b) Crown

Fig. 6 Denture base and crown fabricated from ultra-finegrained material by superplastic forming. (a) Denture base, (b) Crown
水素処理 (真空焼鈍)を行うことで, 水素化物を起点とした微 細な再結晶粒を得ることができる。

Ti-6Al-4V 合金の微細組織を Fig. 4 に示す。結晶粒径は 0.3〜 $0.5 \mu \mathrm{m}$ という, チタン合金バルク材としては極めて微 細な組織になる ${ }^{4)}$ 。 な, 結晶粒界の性質を調べた結果, そ の多くは大傾角粒界で占められていることがわかってい $ろ^{5)}$. この微細化傾向は同じ $\alpha+\beta 2$ 相型チタン合金である $\mathrm{Ti}-3 \mathrm{Al}-2.5 \mathrm{~V}$ 合金や $\mathrm{Ti}-1 \mathrm{Fe}-0.35 \mathrm{O}$ 合金, $\mathrm{Ti}-4.5 \mathrm{Al}-3 \mathrm{~V}-$ $2 \mathrm{Mo}-2 \mathrm{Fe}$ 合金についても確認されている6,7). 以上のことか ら, 水素処理は $\alpha+\beta 2$ 相型チタン合金の結晶粒微細化には 極めて有効な手段である.

水素処理によって微細化したチタン合金の常温における強 度はホールペッチの関係に従って向上4,6) し, そしてある温 度領域に拈いては極めて大きな超塑性伸びを示す5,6) (Fig. 5).この優れた特性を利用して超塑性加工によって試作し た義歯床 ${ }^{8}$ 抢よびクラウン (歯科補綴物 $)^{9)}$ の一例を Fig. 6 に 示す．これらの製造方法として現在，最も多く用いられてい るのが鋳造法であるが，鋳型との反応や寸法精度，薄肉部の 製造が困難であることなど，多くの面で改善が求められてい る.この水素処理によって微細化したチタン合金を用いた超 塑性加工法は, これらの諸問題を解決できる可能性を秘めて

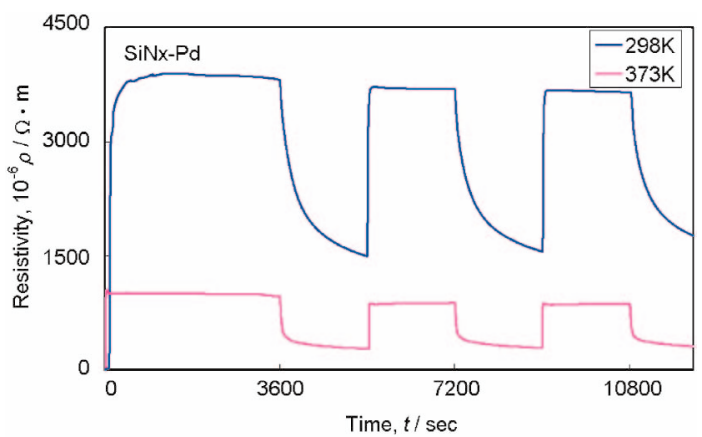

Fig. 8 Resistivities of $\mathrm{SiNx}-\mathrm{Pd} / \mathrm{Y}$ bilayered film as a function of time, during switching hydrogen flowing.

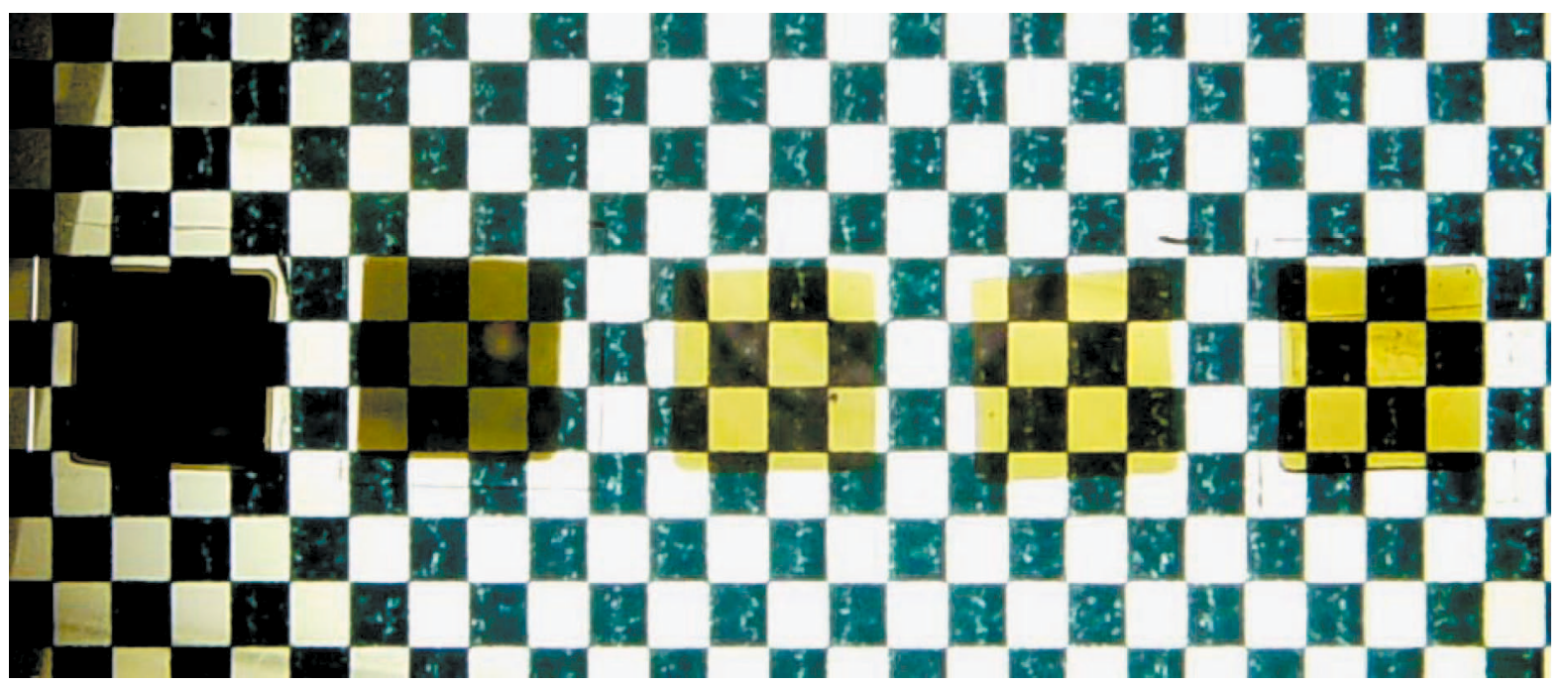

Fig. 7 The outward appearance of hydrogenated $\mathrm{Al} / \mathrm{Y}, \mathrm{Pd} / \mathrm{Y}, \mathrm{AlNx}-\mathrm{Pd} 28$ at\%/Y, AlNx-Pd34 at\%/Y, 1Nx-Pd42 at\%/Y bilayered films. 
おり，今後さらなる微細化による超塑性特性の向上が望まれ る.

上述のように，水素処理はチタン合金の高性能化において は極めて有効であり，また，チタン合金全体の結晶粒を 1 $\mu \mathrm{m}$ 以下に微細化することが可能な, 数少ない方法である. しかし，これまでに水素処理を適用させた例は $\alpha+\beta 2$ 相型 合金のみであり, $\alpha$ 型や near $\beta$ 型, $\beta$ 型といった常温での組 織形態の異なる他のチタン合金については水素処理の適用が 可能かどうか，まだわかっていない，そこで今後，これらの チタン合金に水素処理を施し, 本法による微細化効果, およ び微細化した合金についてはその超塑性についてさらに研究 を進めていく予定である.

\section{3. 材料中における水素固溶誘起の新機能}

\section{1 水素吸放出による光学特性変化を利用した空用材料の 開発}

イットリウム等の希土類金属やマグネシウム基合金などは 水素々結合して結晶構造や物性が大きく変化する．この特性 が注目される端緒になったのは 1996 年の Nature に掲載さ れた論文10)である. Griessen らはその論文で, 希土類金属 薄膜は常温で可逆的かつ高速に水素を吸放出できること，そ の吸放出に伴い光の透過率や電気伝導率が大きく変化するこ とを報告した。その後その性質を応用してスマート空材 料11) 水素センサ12) 開発しようとする報告13,14)が多数発表 されている。

特に透明度を変化させることができるスマート空材料の実 用化への期待が大きい．この材料は赤外域の光透過率も制御 することができるため, 自動車や住宅等の空に活用されるよ うになれば, 冬季の熱流出, 夏季の熱流入を大幅に削減し, 冷暖房に消費されるエネルギー，ひいては二酸化炭素の排出 量を削減することができる．よってこの実用化は社会に与え るインパクトが極めて大きいと言える.

しかし Griessen らの報告から既に 10 年以上経ているにも かかわらず，それらが製品として市販された例は無い。それ には様々な理由があるが, 特に大きな障害となっていたのが 希土類膜を他の元素との反応から保護する材料の問題である.

希土類金属は様々な元素と容易に反応する．例えば大気中 に抢いては速やかに酸化が進行する，従って大気中で使用す るような場合, 表面に何らかの対酸化保護膜を積層すること が通常行われている. 一方でスマート空材料などに用いるに は，希土類層に水素を注入あるいは放出するパスも確保する 必要があるが，事実上それは保護膜中に確保せざるを得な い。すなわち, 保護膜は少なくとも水素は透過する必要があ る.

Griessen らの報告も含め, 一般にはその保護膜にはパラ ジウムが用いられてきた. パラジウムは保護膜としての役割 のみならず, 水素ガスを表面で解離・イオン化させてパラジ ウム自身中に溶かし込む触媒として，そしてその水素イオン を希土類金属層まで輸送する媒体としての役割も有するた め，この目的に適した物質である．しかし一方でパラジウム には多くの問題点も存在し, それが今日まで希土類薄膜の水
素化・脱水素化に伴う現象を活用した製品が実現していない 理由の一つになっている.

ここではまずその問題点をほぼ解決したセラミックスー金 属ナノコンポジット膜と, それを活用した水素センサーの特 性を紹介し, 次いで空用材料の開発について解説する.

セラミックスー金属ナノコンポショット膜はスパッタ法で作 製できる。我々がこれまで作製した窒化アルミニウム $(\mathrm{AlNx})$-パラジウム $(\mathrm{Pd})$, 窒化シリコン $(\mathrm{SiNx})-\mathrm{Pd}$ などの ナノコンポジット薄膜は, 反応性同時スパッタ法にて作製で きた．詳細な作製方法は他に譲るが，この構造を達成するた めに重要なことはセラミックスのマトリックスと Pd などの 金属がほとんど互いに固溶しないということである.

ナノコンポジット膜を高分解能電子顕微鏡で観察すると,

$\mathrm{Pd}$ は直径 $2 \sim 5 \mathrm{~nm}$ のクラスターとなっており，その周りに セラミックスのマトリックスが存在していること, Pd クラ スターは直接にはつながって抢らず，マトリックスによって 分離されていることがわかる. Pd クラスターはバルクと同 じく面心立方晶であり, $\mathrm{SiNx}-\mathrm{Pd}$ の場合マトリックスはシ リコンと窒素の原子比がほぼ $1: 1$ のアモルファスとなって いる.な技, 窒化シリコンは化学量論組成では $\mathrm{Si}: \mathrm{N}=3: 4$ であるので, $\mathrm{SiNx}-\mathrm{Pd}$ 試料中の $\mathrm{SiNx}$ マトリックスは多少窒 素が欠損したものになっている.

Fig. 7 にイットリウムの上に様々な保護膜を積層した試料 を水素雾囲気に打いた後の膜の様子を示す. 左からそれぞれ $\mathrm{Al} / \mathrm{Y}, \mathrm{Pd} / \mathrm{Y}, \mathrm{AlNx}-\mathrm{Pd} 28$ at\%/Y, AlNx-Pd34 at\%/Y, AlNx$\mathrm{Pd} 42$ at\%/Y であり, $\mathrm{Al} / \mathrm{Y}$ 以外は透明になっていることか ら保護膜が水素を透過していることがわかる.ナノコンポジ ット膜などの保護膜を $\mathrm{Y}$ 上に積層し, 水素中に置いた後の 様子を示した様子を示す. $\mathrm{Pd}$ を積層した膜, $\mathrm{AlNx}-\mathrm{Pd}$ を積 層した膜は透明になっており，水素を透過していることがわ かる. $\mathrm{SiNx}-\mathrm{Pd}$ 膜を $\mathrm{Y}$ 上に積層した膜も同様な結果を示 す. 前述したように, コンポジット膜中で Pdナノクラス ターはそれぞれ分離して分布している. そのような構造でも 水素を透過していることから, 水素は Pdのみを通って移動 しているとは考えにくい. この膜の電気抵抗率の温度依存性 を $100 \sim 300 \mathrm{~K}$ の範囲で調べると, 半導体的な負の抵抗温度 係数 (TCR)を示す. SiNx は絶縁体であるので, 電気伝導に はPdの存在が不可欠であるが, もし Pd クラスター同士が 「金属的に」つながってネットワークを形成し, それが電気 伝導の主体となっていれば，金属的な正の TCR を示すはず である. 実際に 50 at\% Pd のコンポジット膜では $200 \mathrm{~K}$ 以 下で正の TCR を示す.

電子でさえ容易に移動できる Pdのネットワークを見つけ られない状況で, 水素が Pdのネットワークを通って移動す る可能性は低いと思われる。したがって AlNx や $\mathrm{SiNx} の マ$ トリックス中にも微量ながら何らかの形で水素が存在できる サイトが存在し，それを介した水素の移動が主な水素移動の メカニズムと考えているが，その検証は今後の課題である.

Fig. 8 に $\mathrm{SiNx}-\mathrm{Pd} / \mathrm{Y}$ 膜の電気抵抗率の時間変化の例を示 す.この例では 3 回の水素化 (1 気圧の水素ガス導入) ·脱水 素化(真空引き)の繰り返しに打方電気抵抗率の変化を示し ている.これは数十回繰り返した場合もほぼ同じような変化 
を示す。また水素を導入してから数秒で電気抵抗率が反応し 始めている。

その後の構造最適化等により, 最近では応答速度 0.5 秒以 下，最少検知濃度 $0.01 \%$ 以下を達成している。

スマート空の材料として用いる場合には，積層した他の層 と水素のやりとりを行うことが不可欠となる．その際，他の 層との界面においては拡散を抑える保護層が必要となる。 た，電界を印加して水素イオンを移動させる場合，水素の移 動速度が大きく, かつ電気抵抗が大きい層を保護層とするこ とが，移動に要する時間とエネルギーを小さくするのに有利 である。このような観点から，我々の開発したナノコンポジ ット膜はスマート空に不可欠な要素素材となると考えている.

現在, 例えば[透明電極/希土類層/ナノコンポジット層/水 素貯蔵層/透明電極/基板]というような様々な積層構造をも ったスマート空の試作が進行中であり，ナノコンポジット層 を通した水素の移動が可能で有ることなどが分かっている. 今後は個々の層の組成や積層構造などの最適化を行い，近い うちに製品化可能なところまで持って行きたいと考えている.

\section{$3.2 \times 夕$ 磁性材料における水素導入による磁歪 ·応力セン シング機能応用}

多くの $\mathrm{Fe}$-希土類化合物において, 磁気的性質は配位数や 原子間距離に敏感に依存することが知られており，結晶構造 に応じて多様な磁性が出現する. また, 侵入型元素により原 子間距離などが变化すると, 自発磁化やキュリー温度が変化 する15,16)。このような性質は, 磁性を担う Fe3d 電子の遍歴 性から説明されるが，他の $3 \mathrm{~d}$ 基化合部にくらべ, 温度·磁 場で誘起される特徵的な相転移現象を示す系が多いのも $\mathrm{Fe}$ 系化合物の特徵である.

筆者らが注目している $\mathrm{La}\left(\mathrm{Fe}_{x} \mathrm{Si}_{1-x}\right)_{13}$ 化合物 $(0.86 \leqq x \leqq$ $0.90)$ は, 低温で強磁性であるが，常磁性に変化する $T_{\mathrm{C}}$ $200 \mathrm{~K}$ に打いて 1 次相転移を示す ${ }^{17)}$. さらに， $T_{\mathrm{C}}$ 直上で外 部磁場を印加すると, 遍歴電子メタ磁性転移と呼ばれる常磁 性一強磁性磁場誘起 1 次相転移を示す。遍歴電子メ夕磁性転 移は, 当初, Wohlfarth らにより理論的にその存在が指摘さ れ18), 後に Co 系化合物を中心として盛んに研究された ${ }^{19)}$. 上述のように, $\mathrm{Fe}$ 系化合物において反強磁性一強磁性転移な ぞの秩序一秩序相転移を示す系は知られているが，遍歴電子 メ夕磁性転移を示す $\mathrm{Fe}$ 系化合物は本系が初めての例である. Wohlfarth らによる遍歴電子メタ磁性転移出現の説明は, Stoner 模型と呼ばれる遍歴電子バンドモデルに基づく. 非 閉内殼の $3 \mathrm{~d}$ バンドは，エネルギー幅が狭く状態密度が大き いが，酸化物などの強相関系とは異なり，遍歴電子同士の クーロン相互作用, すなわち電子相関は散乱と遮蔽によりバ ンド幅より抑えられている6).このため, 電子スピンが揃う ことで排他率に起因するクーロンエネルギーの減少が，バン ド内での運動エネルギーの増加を上回る場合が生じ, 金属状 態での強磁性が出現する。強磁性発生の条件，すなわち Stoner 条件はフェルミ準位での状態密度 $r\left(E_{\mathrm{f}}\right)$ と電子間クー ロン相互作用 $I$ を用いて, $\operatorname{Ir}\left(E_{\mathrm{f}}\right)>1$ で与えられる20)。遍歴 電子メ夕磁性転移においても電子相関と運動エネルギーの関 係が重要であるが, 常磁性からの 1 次転移が生じるために
は，バンド構造の特異性が関係する ${ }^{19)}$ 。すなわち，磁場印 加前の常磁性状態に扔いて, フェルミ準位は状態密度曲線 $r(E)$ に打的高いピーク近傍にあるが，負の曲率を有する $r(E)$ の谷により安定化されている. ゼーマンエネルギーが 加わると, $r(E)$ のピークが $E_{\mathrm{f}}$ にシフトして Stoner 条件を 満たし強磁性状態に転移する. $\mathrm{La}\left(\mathrm{Fe}_{x} \mathrm{Si}_{1-x}\right)_{13}$ 化合物の $3 \mathrm{~d}$ バンドがこのような特徵を有することは筆者らのグループの バンド計算から確認されており21), さらに最近では, 固定 モーメント法と呼ばれる第一原理計算から, 1 次相転移の原 因となる磁気状態間のエネルギー障壁がバンド構造に由来す ることが指摘されている22).

磁場誘起 1 次相転移の場合, 種々の物性にも顕著な变化 を伴うため,さまざまな機能性が期待される. $\mathrm{La}\left(\mathrm{Fe}_{x}\right.$ $\left.\mathrm{Si}_{1-x}\right)_{13}$ 化合物の転移の特徵として, 転移に伴う磁化の変化 が $1 \mathrm{~m}_{\mathrm{B}}$ 程度の大きさを示し, このため, 磁気体積効果を通 じて顕著な体積変化が生じる ${ }^{17,23)}$. 磁気体積効果の原因とし ては，原子間距離とバンド幅の関係によるエネルギー利得も あるが，有限温度の場合には，スピンの摇らぎとよばれる遍 歴電子系特有の素励起の影響が大きいことがわかってい る19). スピンの摇らぎは自由エネルギーへの繰り込久効果 が顕著であるため, キュリー温度 $T_{\mathrm{C}}$ の体積効果が顕著にな る. 例えば, 静水圧を印加した場合には, 強磁性相が不安定 化して $T_{\mathrm{C}}$ が大幅に低下し， $x=0.88$ の化合物では, 圧力係 数 $\mathrm{d} T_{\mathrm{C}} / \mathrm{d} P$ が約 $-40 \mathrm{~K} / \mathrm{GPa}$ に達する ${ }^{23)}$. Fe 濃度を低下さ せると, 転移は 1 次から 2 次型に变化するが, メ夕磁性転 移の原因となる強磁性相の不安定性は保持され， $T_{\mathrm{C}}$ 直下で は圧力に対して磁化が敏感に変化する. このような静水圧に 対する変化を利用すれば, 例えば, 応力センサーとして, 従 来の線磁歪の逆効果の利用からは原理的に得られないような 等方的特性を実現することも可能になる. 本系を材料として 応用する場合，メタ磁性転移を保持して $T_{\mathrm{C}}$ を室温近傍まで 上昇制御することが重要になる. 上述のように, 遍歴電子メ 夕磁性転移は $3 \mathrm{~d}$ 電子状態に由来しているので, 元素置換な ぞによる $T_{\mathrm{C}}$ 制御は，電子状態变化を伴うため有効ではな い. 筆者らは, $\mathrm{La}\left(\mathrm{Fe}_{x} \mathrm{Si}_{1-x}\right){ }_{13} \mathrm{H}_{y}$ において, メ夕磁性転移が 保持されたまま $T_{\mathrm{C}}$ は水素濃度 $y$ に比例して上昇することを 示した ${ }^{24,25)}$. そこで, 本系の応用には, 水素を利用した相転 移制御および水素が果たす役割の解明が大きな意義を有する.

水素吸収後の試料においては, 結晶構造に変化は無く, 格 子定数が等方的に増加する. また, 水素吸収前の $T_{\mathrm{C}}$ の圧力 効果と水素吸収後の格子定数に対する $T_{\mathrm{C}}$ の变化について, 圧縮率を勘案して比較すると, 両者の変化率は比較的近い值 にあり，水素吸収による $T_{\mathrm{C}}$ の上昇は，格子定数増加による 磁気体積効果が主要な原因であると判断される，さらに，メ スバウアー効果測定より得られたアイソマーシフトの值は水 素吸収後に増加しており, $\mathrm{Fe}$ 核周辺の電子濃度が水素吸収 後に減少することがわかった ${ }^{26)}$.この結果は, 水素 $\mathrm{s}$ 電子の $\mathrm{Fe}$ サイトへの顕著な移動は生じておらず, また, 原子間距 離の増加に伴う電子波動関数の重なりが減少していることを 示す.さらに, Fe 核周辺の電場勾配を示す四極子分裂の平 均值に括いては水素化前後の変化が小さいので, 水素吸収に よる体積变化は等方性が高いと言える. 最近の重水素 Dを 
吸収した $\mathrm{La}\left(\mathrm{Fe}_{0.88} \mathrm{Si}_{0.12}\right)_{13} \mathrm{D}_{y}$ の中性子散乱による構造解析の 結果 27$)$ からも，水素原子位置は $24 \mathrm{~d}$ サイトと呼ばれる対称 性が高い位置にあることが示されている，一方，24d サイト が全て占有されると $\mathrm{La}\left(\mathrm{Fe}_{x} \mathrm{Si}_{1-x}\right)_{13}$ の式単位あたり 3 個の 水素が吸収されることになるが，筆者らの水素吸収法の場 合, 吸収量は $\mathrm{La}\left(\mathrm{Fe}_{x} \mathrm{Si}_{1-x}\right){ }_{13} \mathrm{H}_{y}$ に扔いて最大 $y=1.3$ 程度で ある。また，yの值を 0 から最大吸収量まで任意に变化させ た場合， $T_{\mathrm{C}}$ が $y$ に比例して变化する。したがって，特定の 割合で水素占有/非占有が存在する場合でも, 磁気的な变化 には巨視的な等方性が重要な役割を果たしている。このよう な微視的な占有/非占有サイトの差による磁性への影響の有 無などは, 今後, 水素が本系の機能性制御に果たす役割を解 明していく上で，検討を重ねていく事項である.

Fig. 9 には, $\mathrm{La}\left(\mathrm{Fe}_{x} \mathrm{Si}_{1-x}\right){ }_{13} \mathrm{H}_{1.1}$ の静水圧印加に伴う熱磁 気曲線の変化を示す。水素吸収後も 1 次転移を示すため, $T_{\mathrm{C}}$ の顕著な圧力变化が観測される. したがって, 水素化に より $T_{\mathrm{C}}$ を室温近傍に制御した後も，等方的な圧力センサー 材料に応用可能な特徵は保持されている. しかし, 圧力係数 は吸収前に比較してわずかに減少しており，この点について は，水素化に伴う圧縮率の変化なども影響しているので，今 後, 水素化試料における磁気体積効果を詳細に調べる必要が ある。また，新規センサー材料としての応用には，温度安定 性や圧力検出の分解能などの観点から，2次転移的な緩やか な磁化变化も検討の対象となるので, $\mathrm{Fe}$ 抢よび水素濃度の 適切な調整や評価なども必要である。 また, 本系の場合, 水 素吸収により粉末化や不均化が生じないことも，材料応用の 上で重要な特徵である. 以上のように, メタ磁性転移を水素 吸収により制御して機能開発に応用する本研究は, 基礎研究 と材料開発の両面から重要な意義を要しており, 今後の成果 が期待される.

\section{3 水素吸蔵材料としての金属·合金ナノ粒子}

金属の物性は構成原子数 (サイズ)により变化することが久 保により予測され ${ }^{28)}$ ，このサイズ効果は実験的にも証明さ れている，サイズ効果は金属の水素吸蔵など，金属と水素の 反応に㧤ても発現するだろうか? 金属による水素吸蔵抢よ

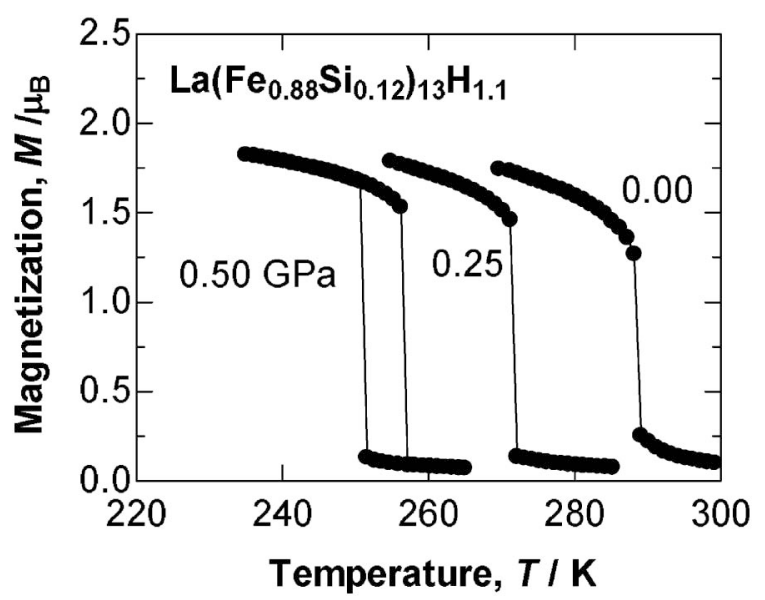

Fig. 9 Temperature dependence of magnetization under hydrostatic pressures for $\mathrm{La}\left(\mathrm{Fe}_{0.88} \mathrm{Si}_{0.12}\right){ }_{13} \mathrm{H}_{1.1}$.
び放出は金属一水素系の相状態を温度および圧力を変化させ ることで達成される。しかし，ナノメートルサイズの金属の 挙動についてはほとんど解明されていない。ここでは, 最も 典型的な吸蔵金属である Pdのサイズ効果について系統的に 実験により得られた結果を報告する。さらに，Pd と同族で ありながらバルクでは水素を吸蔵しない Pt のナノ粒子およ び新たな水素吸蔵材料として Pdをコア，Pt をシェルとする $\mathrm{Pd} / \mathrm{Pt}$ コアシェル型ナノ粒子の水素吸蔵特性の研究ついて得 られた結果を示し，水素吸蔵におけるナノ粒子の役割を議論 する。

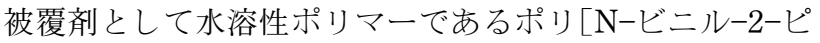
ロリドン」をもちい(以後 PVP と略す)，アルコールによる 化学的還元法により Pdナノ粒子が得られる ${ }^{29,30)}$. PVP は解 離性の水素を含まず，金属表面と強い結合を作らないことか ら，金属ナノ粒子自体の水素吸蔵特性を評価するのに適して いる.

粒径 $2.6 \pm 0.4 \mathrm{~nm}$ および $7.0 \pm 0.9 \mathrm{~nm}$ の $\mathrm{Pd}$ ナノ粒子およ びバルクの参照として Pd 黒の PCT 曲線を Fig. 10 (a), (b) に示す．Pd 金属のサイズが減少するにつれて二相共存の領 域が狭くなっている。これは, 固溶体の最大水素濃度はバル クに比べて大きく, 水素化物の最小濃度は小さくなっている ことに対応する ${ }^{31)}$.これまでにも, 直径 2-3 nmの Pdナノ 粒子の水素化物相に打ける水素濃度はバルク Pdに比べて減 少するとの報告があり, その原因は, ナノ粒子の表面が吸蔵 に不活性であるためと解釈された ${ }^{31)}$. しかし，Pdナノ粒子 の表面原子数の全原子数の割合の変化と水素濃度には強い相 関がみられないことから, Pdナノ粒子における水素吸蔵量 の減少は表面原子のみの単純な問題ではないと言える. 報告 にしたがい，ナノ粒子表面水素化物が形成されないとすると， $\mathrm{Pd}$ ナノ粒子内部の水素濃度は直径 $7.0 \mathrm{~nm}$ の粒子でバルク $\mathrm{Pd}$ と同程度， $2.6 \mathrm{~nm}$ の粒子ではその 1.2 倍程度となる。し たがって，Pdナノ粒子の内部にはバルクよりも高密度に水 素が吸蔵されていると予想される。

金属の水素吸蔵に打けるサイズ依存性を熱力学的に定量す ることは，ナノメートルサイズの金属の特性を知る上で非常 に重要である。PCT 線の平衡水素圧力から見積もった $\mathrm{Pd}$ 黒抢よびナノ粒子中の水素化物形成の際の生成熱 $(-\mathrm{D} H)$ と 標準エントロピー $(-\mathrm{DS})$ を Fig. $10(\mathrm{c}),(\mathrm{d})$ に示す。 -DHは $\mathrm{Pd}$ と $\mathrm{H}$ が別々に存在する状態から水素化物を形成したとき の安定化エネルギーであり，-DS は金属内の水素の配置あ るいはバンド内の電子配置に関係する量である. Fig. 10 (c) に拈いて Pd 黒の-DHが一番大きく，サイズ減少とともに 小さくなることが明らかとなった。これは，Pdのサイズが 減少すると水素化物形成によって得られる安定化エネルギー が減少することを示している，したがって，Pd はバルクの 状態(電子状態抢よび構造特性)が水素との結合を作るのに最 も適した状態であり，サイズが減少すれば水素化物の安定性 は失われることがわかった．Fig. 10(d)から，-DS は Pd 黒 が一番大きく, サイズ減少により減少することがわかった。 これは，Pdナノ粒子中の水素の配置には乱れがあり，バル クの水素化物よりも大きなエントロピーを有していることを 意味している.ナノ粒子に打ける平衡水素圧力および臨界温 
度の低下は，水素化物への転移に打ける小さな生成熱，そし て，ナノ粒子水素化物の大きなエントロピーにより説明する ことが出来る.

Fig. 11 に, 直径 $2.0 \pm 0.3 \mathrm{~nm}$ の $\mathrm{Pt}$ ナノ粒子と $\mathrm{Pt}$ 黒の $303 \mathrm{~K}$ に打ける PCT 線の測定結果を示す．Pt 黒は表面吸着 に由来して二回目の測定にお污る水素吸着量は大幅に減少し た. Ptナノ粒子で観測された約 $0.1 \mathrm{kPa}$ 以下でおこる水素 吸蔵挙動もこの表面吸着によるものと考えられる。しかし, ナノ粒子での水素の表面吸着は, 測定回数を繰り返しても観 測されたことから，Pt 表面の水素との相互作用はバルクと
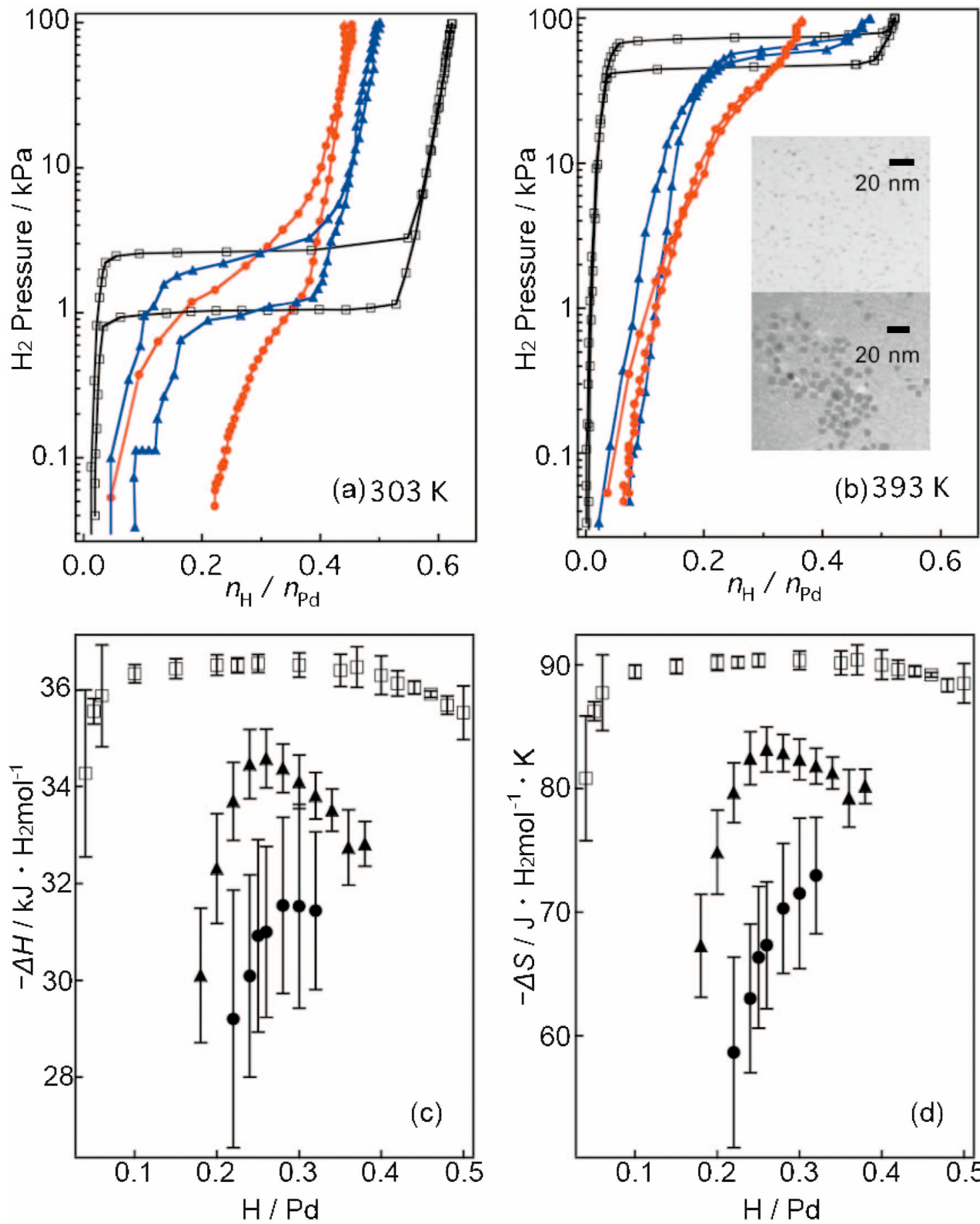

は異なっていることがわかる. Pt 黒は $0.1 \mathrm{kPa}$ 以上での水 素吸蔵量の増加は観られなかった。一方, $\mathrm{Pt}$ ナノ粒子で は, 圧力の増加にともなって水素吸蔵量が増加した。これは, $\mathrm{Pt}$ ナ八粒子は水素と $\mathrm{Pt}$ 水素化物を形成し, 格子内部に水素 を吸蔵することを表している．Ptをナノメートルサイズに することでその化学反応性が変化し，バルク金属にはない特 性が表れると考えられる.

Pd よりも還元しやすい Pt イオンを還元して Pd 粒子表面 に析出させるには犠牲水素法が用いられる。この手法により, Pd をコア，Pt をシェルとする，ナノ粒子に特有な相分離型

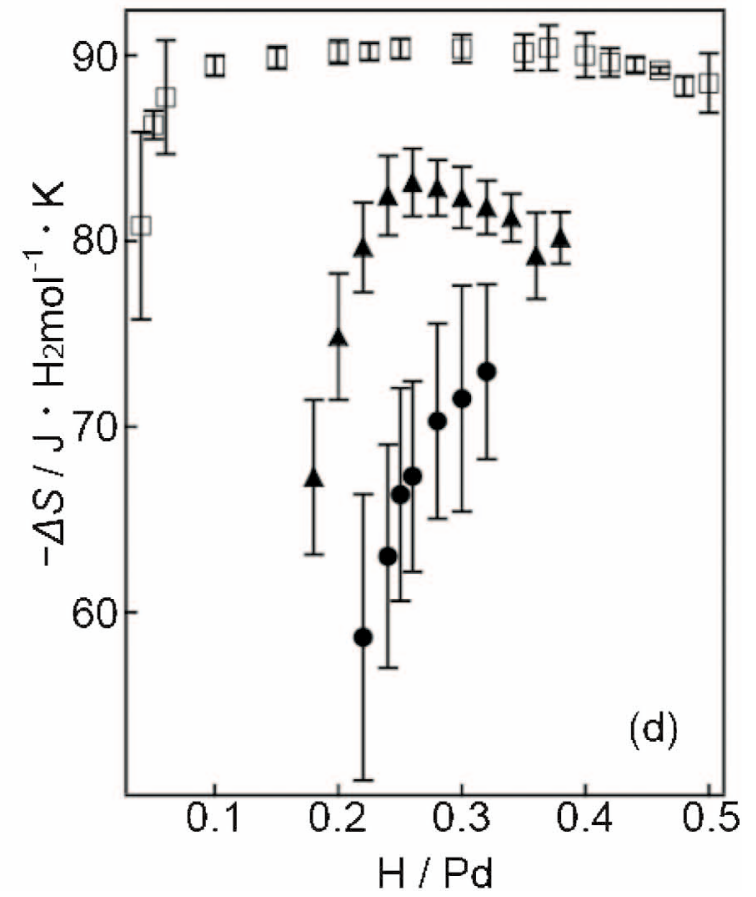

Fig. 10 Hydrogen pressure-composition (PC) isotherms for $\mathrm{Pd}$ nanoparticles with a diameter of $2.6 \pm 0.4(\mathbf{O})$ and $7.0 \pm 0.9 \mathrm{~nm}$ ( $\Delta$ ) and for Pd black ( $\square$ ) measured at (a) 303 and (b) $393 \mathrm{~K}$. (c) Enthalpy change $(\Delta H)$ and (d) entropy change $(\Delta S)$ in the hydride formation. These thermodynamic quantities were determined by the analyses of the PC isotherms. 


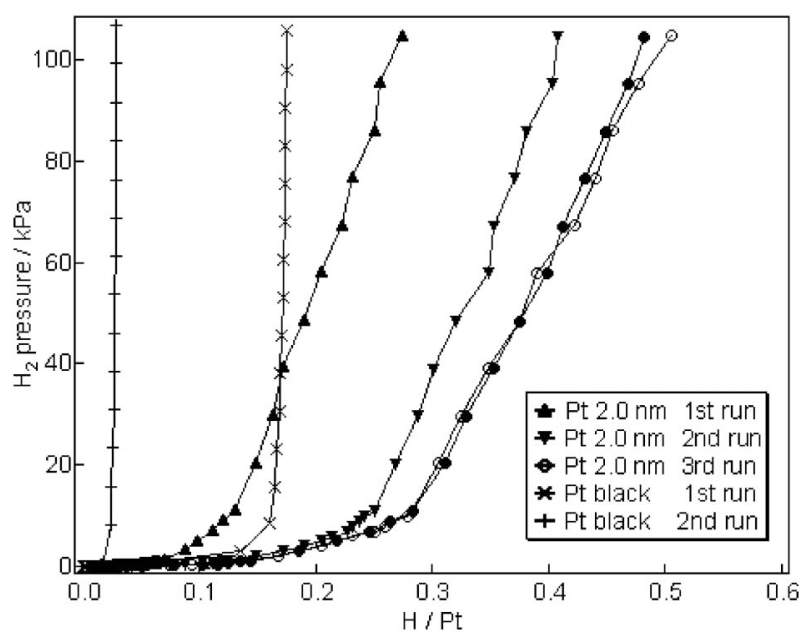

Fig. 11 Hydrogen pressure-composition isotherms for the $\mathrm{Pt}$ nanoparticle with a diameters of $2.0 \pm 0.3 \mathrm{~nm}$ and for Pt black.

合金が作製される32)、コアとシェルの間には，ナノメート ルスケールの異種金属界面(ヘテロ界面)が存在し，バルク合 金にはない，新たな水素のサイトの形成が期待される．直径 $6.1 \pm 0.8 \mathrm{~nm}$ の $\mathrm{Pd}$ ナノ粒子に $1.0 \mathrm{~nm}$ の厚みの $\mathrm{Pt}$ シェルか らなる $\mathrm{Pd} / \mathrm{Pt}$ ナノ粒子の水素加減圧下による粉末 $\mathrm{X}$ 線回折 (XRD) 測定を行った．真空下に抢ける $\mathrm{Pd} / \mathrm{Pt}$ 粒子の回折パ ターンはPd と Pt の fcc 格子からの回折の重なりで再現で きた.この粒子の回折パターンは水素を一気圧まで加圧し, 再び減圧してもほとんど変化は観測されなかった．この結果 から， $\mathrm{Pd} / \mathrm{Pt}$ 合金はそのコア抢よびシェル金属の格子内部に 水素を固溶しないことが明らかとなった．

次にこの試料の PCT 線, およびコア部に用いた Pdナノ 粒子の PCT 水素圧力を Fig. 12 上図に示す. 横軸には, 固 溶している水素の数を全構成金属数で割った值を示しており, $\mathrm{Pt}$ を含めた仮想的な合金一粒子当たりの水素溶解度に対応 する. $\mathrm{Pd}$ 抢よび $\mathrm{Pd} / \mathrm{Pt}$ 粒子ともに水素圧力の増加ともに水 素溶解度が増大した。驚くべきことに水素溶解度はバルクで は水素を吸蔵しない $\mathrm{Pt}$ を含むコアシェル型合金の方が大き いことがわかった。この結果は, $\mathrm{Pd} / \mathrm{Pt}$ ナ粒子はその格子 内に水素を固溶しないというXRD の結果と矛盾しているよ うにみえる。

ポリマーは多量の ${ }^{1} \mathrm{H}$ 核を含むため, 重水素ガス $\left({ }^{2} \mathrm{H}_{2}\right)$ を 吸蔵させたナノ粒子試料の ${ }^{2} \mathrm{H}$ 固体 NMR 測定を行った.

Fig. 12 下図に Pd 抢よび Ptナノ粒子, Pd/Ptナノ粒子の ${ }^{2} \mathrm{H}$ NMR スペクトルを示す. 最大の吸収は Pd 抢よび Ptナ ノ粒子試料では 34 と-36 ppm に観測された. $\mathrm{Pd} / \mathrm{Pt}$ ナノ粒 子については, $\mathrm{Pd}, \mathrm{Pt}$ ナノ粒子のスペクトルの観測領域に わたる幅の広い吸収が反られた。 また，そのピーク位置は $\mathrm{Pd}$ と $\mathrm{Pt}$ のそれぞれのスペクトルの中間であった．XRDの 結果をあわせると, $\mathrm{Pd} / \mathrm{Pt}$ ナノ粒子中の水素は $\mathrm{Pd}$ 打よび $\mathrm{Pt}$ の格子内部よりも，その間の領域つまりへテロ界面に多く存 在すると考えることができる.Pd と Ptのつくるへテロ界面 は, 個々の要素金属格子内部より, 水素が安定存在するのに 適したポテンシャルを提供することが明らかとなった。

$\mathrm{Pd}-\mathrm{H}_{2}$ 系では水素溶解度, 平衡水素圧, 臨界温度などに
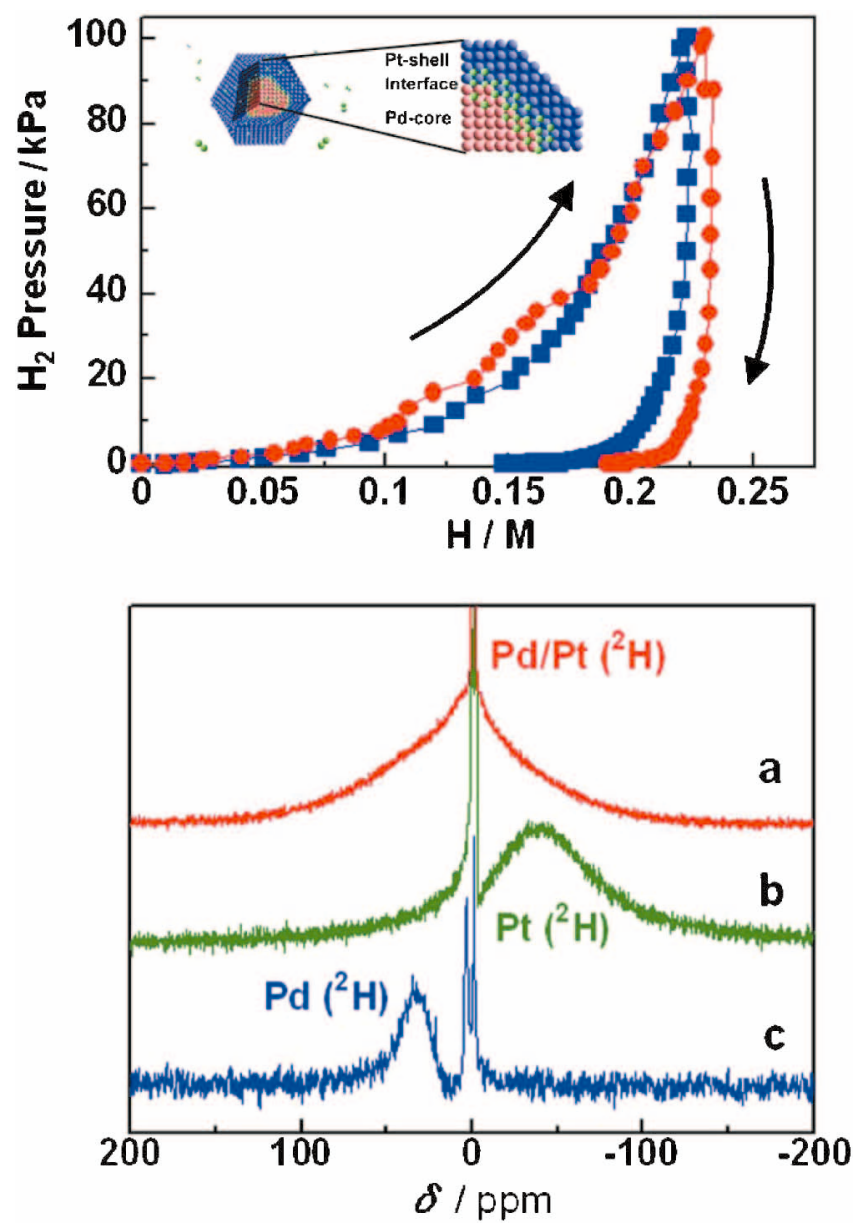

Fig. 12 Hydrogen composition isotherms for $(\mathbf{P d} \mathrm{Pd} / \mathrm{Pt}$ nanoparticles and $(\boldsymbol{\square})$ core- $\mathrm{Pd}$ nanoparticles (upper) and ${ }^{2} \mathrm{H}$ NMR spectra for deuteron absorbed in (a) $\mathrm{Pd} / \mathrm{Pt}$ nanoparticles, (b) Pt nanoparticles, and (c) Pd nanoparticles.

顕著なサイズ依存性が観測された．また，ナノ粒子の持つ高 い触媒活性と大きな自由度 (エントロピー大)により, 動作温 度および圧力が低減することが示唆された．Pt のナノ粒子 に水素が多量に溶解することもわかった．また，Pd/Ptコア シェルナノ粒子では, コアシェルの界面に大量の水素が吸蔵 され，さらに，Pt を含む金属一個あたりの吸蔵量が Pdナノ 粒子よりも大きいことが明らかとなった，水素の吸蔵特性に は金属のサイズつまりその電子状態が深く関わって抢り, サ イズ抢よび合金構造を精密にコントロールすることで,バル ク材料にはない機能性材料の創製が期待される.

\section{4. ま と め}

前述のように, 材料, 特に金属に対する水素という元素が 持つ機能に着目し, 平成 19 年度開始の元素戦略プロジェク ト「サブナノ格子物質中に打る水素が誘起する新機能」で 推進されているサブテーマの研究結果の一部を報告した. 水 素処理による結晶粒微細化については, その機構が幾つか議 論されているが，微細化により得られる粒径などについての 議論が未検討な部分も多い. 一方, 材料中の水素により誘起 される機能については, ここ 10 年で基礎的な理解について 
深まっている．最近では応用用途についての議論が飛躍的な 進展を示しており，今後の開発が期待される.

本研究は, 文部科学省・元素戦略プロジェクト「サブナノ 格子物質中に抢ける水素が誘起する新機能」の委託費を受け て実施された。

文 献

1) T. Takeshita and R. Nakayama: Proc. the 10th International Workshop on Rare-Earth Magnets and their Applications Kyoto, (1989) pp. 551-556.

2) A. Kamegawa, T. Funayama, J. Takahashi, H. Takamura and M. Okada: Mater. Trans. 46 (2005) 2449-2453.

3) T. Funayama, J. Takahashi, A. Kamegawa, H. Takamura and M. Okada: J. Jpn. Soc. Powder Powder Metallurgy 52 (2006) 874-878.

4) J. Nakahigashi and H. Yoshimura: J. Soc. Mat. Sci. Jpn. 49 (2000) $1307-1311$.

5) J. Nakahigashi and H. Yoshimura: J. Japan Inst. Metals 65(2001) 1096-1103.

6) J. Nakahigashi, K. Takahiata, K. Tsuru, T. Sumimoto, H. Yoshimura and H. Horimura: J. Japan Inst. Metals 70(2006) 204-211.

7) J. Nakahigashi: Collected Abstracts of the 2008 Spring Meeting of the Japan Inst. Metals, (2008) p. 159.

8) J. Nakahigashi and H. Yoshimura: Mater. Trans. 43(2002) 2768-2772.

9) J. Nakahigashi, K. Tsuru and H. Yoshimura: J. J. Dent. Mater. 24(2005) 291.

10) J. N. Huiberts, R. Griessen, J. H. Rector, R. J. Wijngaarden, J. P. Dekker, D. G. Groot and N. J. Koeman: Nature 380 (1996) 231-234.

11) E. S. Matveeva, R. J. O. Ramiro, A. S. Bolinchez, C. Ferrer, Jimenez and V. P. Parkhutik: Sensors and Actuators B 84
(2002) 83-90

12) G. Bour, A. Reinholdt, A. Stepanov, C. Keutgen and U. Kreibig: Eur. Phys. J. D16 (2001) 219-223.

13) M. Okada et al.: Hydrogen World Exploring the 21st Century, (KUBA PRO, 2003) p. 80

14) M. Okada et al.: Hydrogen World Exploring the 21st Century, (KUBA PRO, 2004) p. 57.

15) G. Wiesinger and G. Hilscher: Handbook of Magnetic Materials, ed. by K. H. J. Buschow, (Elsevier, 1991) vol. 6, pp. 511-584

16) H. Fujii and H. Sun: Handbook of Magnetic Materials, ed. by K. H. J. Buschow, (Elsevier, 1995) vol. 9, pp. 303-404.

17) A. Fujita, Y. Akamatsu and K. Fukamichi: J. Appl. Phys. 85 (1999) 4756-4758.

18) E. P. Wohlfarth and P. Rhodes: Philos. Mag. 7(1962) 18171824.

19) H. Yamada, K. Fukamichi and T. Goto: Phys. Rev. B 65 (2001) 024413: 1-6.

20) K. Yosida: Theory of Magnetism, (Springer, 1996) pp. 201-220.

21) A. Fujita, K. Fukamichi, J. T. Wang and Y. Kawazoe: Phys. Rev. B 68(2003) 104431: 1-6.

22) M. D. Kuz'min and M. Richiter: Phys. Rev. B 76 (2007) 092401: $1-4$.

23) A. Fujita, S. Fujieda, K. Fukamichi, H. Mitamura and T. Goto: Phys. Rev. B 65(2001) 014410: 1-6.

24) A. Fujita, S. Fujieda, K. Fukamichi, Y. Yamazaki and Y. Iijima: Trans. Mater. Res. Soc. Jpn. 26 (2001) 219-222.

25) S. Fujieda, A. Fujita, K. Fukamichi, Y. Yamazaki and Y. Iijima: Appl. Phys. Lett. 79(2001) 653-655.

26) A. Fujita, S. Fujieda and K. Fukamichi: J. Magn. Magn. Mater. (2008) in press.

27) S. Fujieda, A. Fujita and K. Fukamichi: J. Phys. Soc. Jpn. $\mathbf{7 7}$ (2008) 074722: 1-8.

28) R. Kubo: J. Phys. Soc. Jpn. 17 (1962) 975.

29) N. Toshima, M. Harada, T. Yonezawa, K. Kushihashi and K. Asakura: J. Phys. Chem. 95 (1991) 7448-7453.

30) T. Teranishi and M. Mikio: Hyomen 35 (1997) 439.

31) M. Yamauchi, R. Ikeda, H. Kitagawa and M. Takata: J. Phys. Chem. C 112 (2008) 3294-3299.

32) H. Kobayashi, M. Yamauchi, H. Kitagawa, Y. Kubota, K. Kato and M. Takata: J. Am. Chem. Soc. 130 (2008) 1828-1829. 